\section{THE IMPACT OF WORK-RELATED PSYCHOSOCIAL FACTORS ON THE HEALTH AND WORK ABILITY OF MUNICIPAL TRANSIT AGENTS}

\author{
O impacto de fatores psicossociais do trabalho sobre a saúde \\ e a capacidade de trabalho dos agentes de trânsito municipais
El impacto de los factores psicosociales del trabajo para la salud y la capacidad de trabajo de agentes de tráfico municipales

\begin{abstract}
Objective: To analyze the impact of work-related psychosocial factors on the health and work ability of municipal transit agents. Methods: A cross-sectional study was carried out with a sample of 118 subjects at the municipality of Rio de Janeiro, Rio de Janeiro State, Brazil, during 2014. They answered two questionnaires: Work Ability Index - WAI and Copenhagen Psychosocial Questionnaire - COPSOQ. These questionnaires collected information regarding how well a worker is able to perform his or her work; and on the psychosocial factors related to their work, health status, and welfare. The statistical analyses were carried out using the calculation of central tendency and dispersion measures. Results: The analysis of objectivity, acceptance, practicability, sensitivity and content validity of the questionnaires as a whole did not show any problematic result, with some limitations regarding their length. A significant association between WAI and COPSOQ was observed. The prevalence of good capacity for work was among the subjects aged between 31 and 50 years $(\mathrm{p}=0.012)$. However, concerning the job satisfaction, $28(23.73 \%)$ denoted being satisfied, $74(62.71 \%)$ partly satisfied, and 16 (13.56\%) were dissatisfied. The ability index was 36.8 points, and the prevalence of good capacity for work was $76.27 \%$. Conclusion: The results revealed that better physical and mental health are associated with greater work ability, representing that, the better the worker's health, the greater his work ability. The psychosocial work environment and, especially, the decision-making autonomy were thus important determinants of self-rated quality of life in this group of transit agents.
\end{abstract}

Descriptors: Work Capacity Evaluation; Psychosocial Impact; Health Policy; Health Promotion.

\section{RESUMO}

Objetivo: Analisar o impacto de fatores psicossociais no trabalho sobre a saúde e a capacidade de trabalho dos agentes de trânsito municipais. Métodos: Um estudo transversal foi realizado com uma amostra de 118 indivíduos no município do Rio de Janeiro, Estado do Rio de Janeiro, Brasil, em 2014. Eles responderam dois questionários: Índice de Capacidade para o Trabalho - ICT e Copenhagen Psychosocial Questionnaire - COPSOQ. Estes questionários coletaram informações sobre o quão bem um trabalhador é capaz de realizar o seu trabalho e sobre os fatores psicossociais no trabalho, na saúde e no bem-estar do trabalhador. As análises estatísticas foram realizadas utilizando o cálculo de medidas de tendência central e dispersão. Resultados: A análise de objetividade, de aceitação, de viabilidade, de sensibilidade e de validade de conteúdo do questionário como um todo não mostrou resultados problemáticos, com algumas limitações quanto ao comprimento deles. Observou-se uma associação significativa entre a ICT e COPSOQ. A prevalência de boa capacidade de trabalho está entre os individuos com idades entre 31 e 50 anos $(p=0,012)$. No entanto, quanto à satisfação no trabalho, 28 (23,73\%) denotaram estar satisfeitos, 74 $(62,71 \%)$ intermediariamente e $16(13,56 \%)$ insatisfeitos. $O$ indice de capacidade foi de 36,8 pontos, e da prevalência de boa capacidade para o trabalho foi 76,27\%. Conclusão: Os resultados revelaram que uma melhor saúde física e mental está associada a maior
Original Article
1) Sergio Arouca National School of Public Health - Oswaldo Cruz Foundation (Escola Nacional de Saúde Pública Sergio Arouca, Fundação Oswaldo Cruz - ENSP/ FIOCRUZ) - Rio de Janeiro (RJ) - Brazil

2) Coordination Nucleus of Worker Health Policies - Federal University of Rio de Janeiro - (Núcleo de Coordenação de Políticas de Saúde do Trabalhador, Universidade Federal do Rio de Janeiro CPST/UFRJ) - Rio de Janeiro (RJ) - Brazil
Received on: 07/14/2016 Revised on: 09/06/2016 Accepted on: 11/18/2016 
capacidade de trabalho representando que, quanto melhor a saúde do trabalhador, maior a sua capacidade de trabalho. O ambiente de trabalho psicossocial e, especialmente, a autonomia de decisão foram, portanto, determinantes importantes da qualidade de vida auto-avaliada nesse grupo de agentes de trânsito.

Descritores: Avaliação da Capacidade de Trabalho; Impacto Psicossocial; Política de Saúde; Promoção da Saúde.

\section{RESUMEN}

Objetivo: Analizar el impacto de los factores psicosociales del trabajo para la salud y la capacidad de trabajo de los agentes de tráfico municipales. Métodos: Estudio transversal realizado con una muestra de 118 sujetos en el municipio de Rio de Janeiro, en el estado de Rio de Janeiro, Brasil, en 2014. Los participantes contestaron a los cuestionarios: Work Ability Index - WAI y Copenhagen Psychosocial Questionnaire - COPSOQ. Los cuestionarios reúnen informaciones respecto lo bien que un trabajador es hábil para actuar en su trabajo; y los factores psicosociales del trabajo, el estado de salud y el bienestar del trabajador. Los análisis estadísticos fueron realizados utilizando el cálculo de las medidas de tendencia central y de dispersión. Resultados: Los análisis de objetividad, aceptación, viabilidad, sensibilidad y validez de contenido de los cuestionarios en su totalidad no han demostrado ningún resultado problemático con limitaciones relacionadas a sus tamaños. Fue observada una asociación significativa entre el WAI y el COPSOQ. La prevalencia de buena capacidad de trabajo fue encontrada en sujetos entre los 31 y 50 años de edad (p=0,012). Sin embargo, respecto la satisfacción del trabajo, 28 (23,73\%) relataron satisfacción, 74 (62,71\%) satisfacción intermedia y 16 (13,56\%) no satisfacción. El index de habilidad fue de 36,8 puntos y la prevalencia de buena capacidad de trabajo fue del 76,27\%. Conclusión: Los resultados revelaron que la mejor salud fisica y mental es asociada a una mejor habilidad de trabajo, o sea, a mejor salud del trabajador mejor su habilidad de trabajo. El ambiente psicosocial de trabajo y en especial la autonomía de decisión han sido determinantes importantes de calidad de vida en ese grupo de agentes de tráfico.

Descriptores: Evaluación de Capacidad de Trabajo; Impacto Psicosocial; Politica de Salud; Promoción de la Salud.

\section{INTRODUCTION}

The maintenance of ability to work of employees is related to their health condition and professional context ${ }^{(1)}$. This relationship is supported by the good functioning of living conditions, a favourable quality of life, increasing productivity and consequently leading to decreased job abandonment at a later age ${ }^{(2)}$. This was, social and economic costs for the worker and for society are reduced ${ }^{(3,4)}$.

The work ability is guided by numerous issues, including social and demographic characteristics, the lifestyle, the health state and aspects associated to work ${ }^{(4)}$.
The interest in developing this study of transit agents relates to the fact that, among the various professional classes, this stands out as being one of the sectors most affected by psychosocial factors, including the stress labor ${ }^{(5,6)}$. The World Health Organization has estimated 217 million cases of occupational diseases ${ }^{(7)}$. Notwithstanding, stressful events such as poor working conditions, poor organization, lack of control over work tasks and conflicting labor relations, in the long term, cause organic changes that can, among other consequences, compromise worker performance ${ }^{(8)}$. The posture, physical and intellectual effort, the number of working hours, also considering the shifts, worker motivation and interpersonal relations have been reported in several studies as some of the most important factors to consider in occupational health ${ }^{(9,10)}$. Also, the degree of participation in the labor, environment and organization of work, and its rhythm, intensity and autonomy are among the many factors that affect the health of workers in a less obvious form ${ }^{(11,12)}$.

The promotion of capacity for work aims to: improve working conditions, the environment and the organization of work, promote health and professional competence of workers $^{(13)}$. The positive results for workers, companies and society in general, are: increased productivity resulting from improved capacity for work, increased work efficiency and effective working time, reducing absenteeism ${ }^{(1,7)}$.

Throughout times, there have been changes, which require restructuring work processes, such as the introduction of new technologies in order to improve production quality and quantity; more demands on workers, qualifications and working hours. These and other factors lead to adverse effects, including psychosocial factors at work, stress and fatigue ${ }^{(7)}$. The wear deriving from work demands can be linked to chronic and acute physiological responses, psychological reactions and behavioural changes, with the possibility of decreased functional capacity and ability to work, and can trigger work-related diseases ${ }^{(14)}$. On the other hand, requirements that are characterized as positive can promote and protect the health, work capacity and functional capacity, whatever the age of the worker ${ }^{(3)}$.

If, on one hand, the work plays an essential role in personal development and social life ${ }^{(15)}$, on the other, as it becomes more individualized and demanding at the psychic level, it may even lead to imbalance of the mental health of workers ${ }^{(8)}$. Psychosocial risks at the workplace have been identified as significant emerging risks. Linked to psychosocial risks, issues such as work-related stress and workplace violence are widely recognized as major challenges to occupational health and safety ${ }^{(16)}$. In fact, several studies show a strong association between the psychological requirements of work and the occurrence of minor mental disorders ${ }^{(17,18)}$. 
Thus, the Occupational Health focuses on the promotion and maintenance of physical and psychosocial health of those in their workplace, taking into account the various factors that influence the labor quality, health and wellness ${ }^{(11,15)}$. In this context, determining the work ability has increasingly gained relevance and has been recently used as an important tool to predict workers' capabilities to perform their tasks in the future ${ }^{(3,19)}$. In addition, maintaining good work ability has become increasingly important in prolonging working life and reducing workforce losses ${ }^{(1,20,21)}$.

The objective of this study was to analyse the impact of psychosocial factors at work on the health and work ability of municipal transit agents.

\section{METHODS}

A cross-sectional study was carried out among municipal transit agents. Data collection was performed using questionnaires to measure work ability [Work Ability Index (WAI) $\left.{ }^{(1)}\right]$, and work-related psychosocial hazards [Copenhagen Psychosocial Questionnaire (COPSOQ) ${ }^{(22)}$ ].

A total of 118 municipal transit agents employed at the 3rd Special Transit Group of the municipality of Rio de Janeiro, Rio de Janeiro, Brazil, which acts in the districts of Jacarepaguá, Barra da Tijuca and Campo Grande, were included in this study, in 2014 (Figure 1).

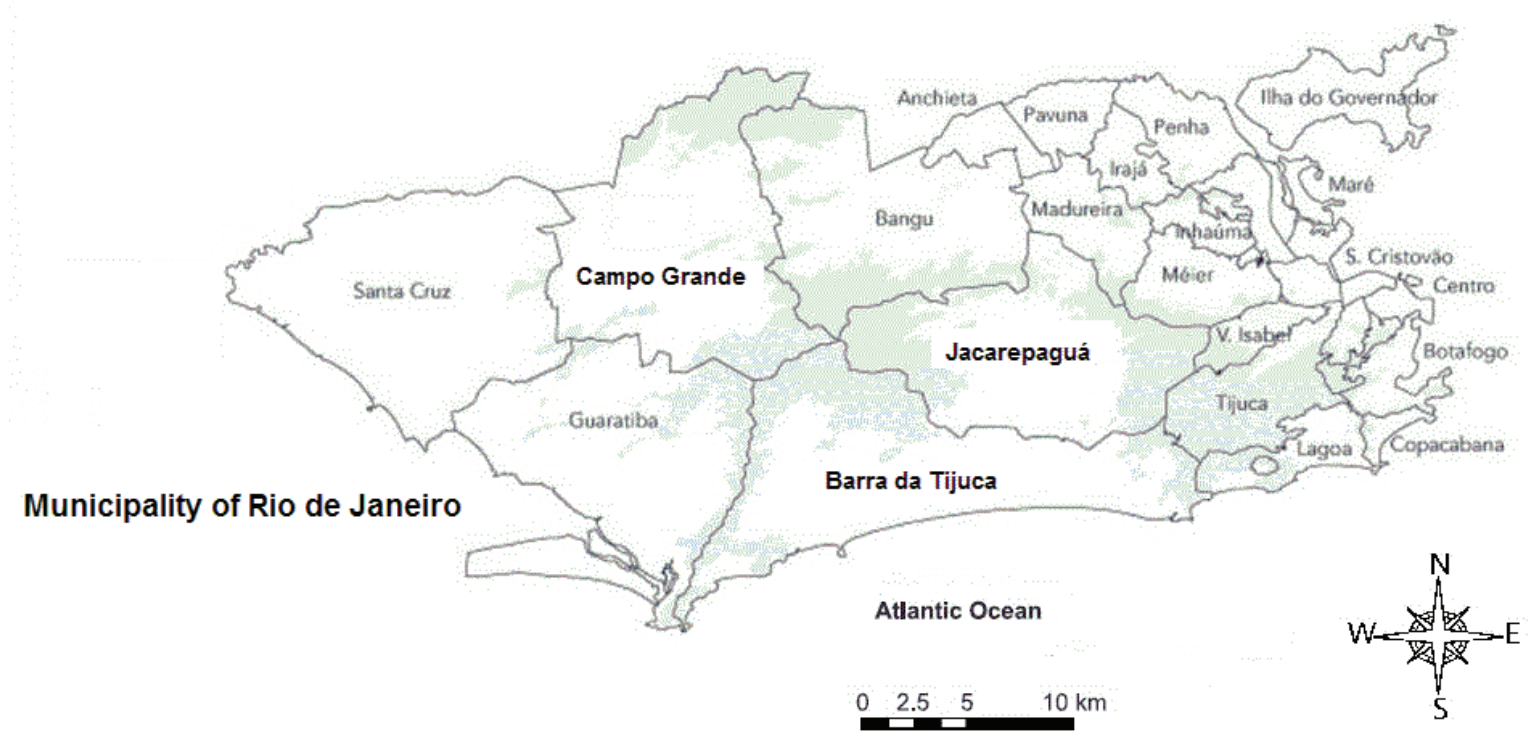

Figure 1 - Study area: Localization of districts - Jacarepaguá, Barra da Tijuca and Campo Grande. Rio de Janeiro, RJ, Brazil, 2014.

The process of obtaining data on transit agents' occupational activities was planned, implemented and evaluated according to the model described ${ }^{(23)}$ (Figure 2), with the evaluation process in occupational safety and health grouped in three phases: development, implementation and effect evaluation. Each phase consists of five central tasks: gathering background information; developing partnership; choosing methods and design; completing development, implementation and evaluation; and reporting and disseminating the process and results. The process described encourages going a step backwards whenever the five tasks in each phase have been completed, in order to evaluate and improve the development, implementation and occupational evaluation.

The COPSOQ ${ }^{(22)}$ is a standardized measuring instrument designed to monitor different aspects of the psychosocial work environment. This questionnaire is designed to evaluate psychosocial factors at work, health and welfare of workers. It consists of 128 questions distributed in 34 dimensions. These dimensions appear grouped into four categories: the working environment factors, local work values, conflict between work and family factors, individual factors.

Questions are answered on a Likert scale with five response options (Always, Often, Sometimes, Rarely and Never/Almost Never), and each of these answer choices is assigned a value $(0,25,50,75$ and 100 , respectively). All scales are listed from 0 to 100 . Each dimension is calculated from the mean scores of the items that make up that same dimension.

The COPSOQ tries to deal with the broadness and indefiniteness of the psychosocial factors by applying a 


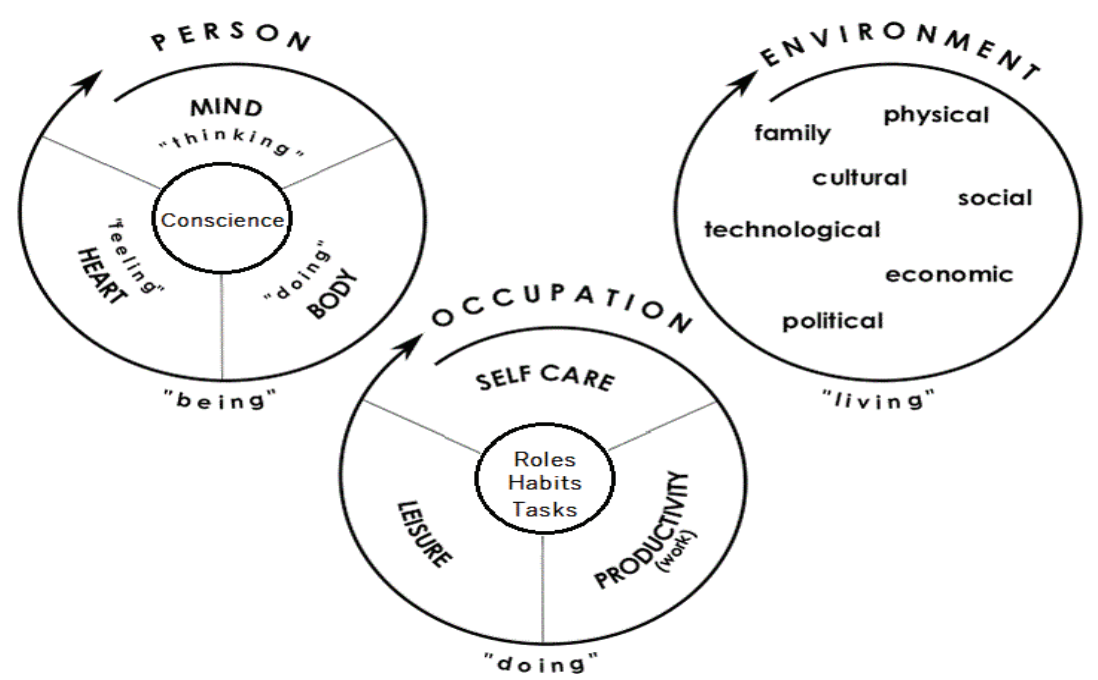

Figure 2 - Depiction of the Person-Environment-Occupation Model of Occupational Performance (Law et al. $\left.{ }^{(23)}\right)$.

multidimensional approach with a very wide spectrum of ascertained aspects ${ }^{(23)}$. It presents itself as a multidimensional instrument, a tripartite methodology. It is a powerful tool that brings together international consensus on the validity of modernity and comprehensiveness in the evaluation of many of the most relevant psychosocial dimensions inherent to the work context ${ }^{(24,25)}$.

The work ability index (WAI) is determined based on the answers to a series of questions that take into consideration the physical and mental demands of work and the worker's health status and resources. The work ability evaluation was done by applying the WAI developed by Finnish researchers and based on workers' self-perception ${ }^{(7,26,27)}$. It is composed of seven aspects: 1) the person's current work capacity compared with the best of their life; 2) the work capacity compared with the work demands; 3 ) total number of selfperceived diseases diagnosed by the physician; 4) estimated work loss due to illness; 5) absence from work due to illness; 6) self-prognosis of work capacity; and 7) mental resources. The results can vary between a score of 7 to 49 points, where scores from 7 to 27 represent the group with low work capacity, 28 to 36 with moderate capacity, 37 to 43 good capacity, and 44 to 49 with excellent work capacity. The results can be used collectively or individually.

A pilot study was undertaken during 2013 to check the suitability of the questions for the study population. The interviews were done by two trained interviewers, both with graduate education. During preliminary meeting for the research, the research proposal was presented to the participants, who were given information about the procedures involved and the invitation to participate.
Participation in the study was formalized by signing the informed consent form.

For data collection, there was the application of face-to-face interviews, consisting of a self-completion questionnaire. The interviews took place at the headquarters of the 3rd Special Transit Group, in Rio de Janeiro, RJ, Brazil, and its quantitative varied between 4 and 10 on Wednesdays during the period of research. All subjects were aware of the objectives of the study and had the informed consent signed. Exclusion criteria were: being on sick leave, having participated in the pre-test, being on vacation during data collection, and having answered incompletely to any of the questions posed.

The target study population consisted of 162 workers, $29(17.9 \%)$ of which were excluded because they were away, changed function or were in vacation during the period of data collection. From 133 people who met the study criteria, 5 were attending external courses, travelling on duty or could not be found, thus remaining 128 (79\%) workers contacted. Among the 128 workers, three did not respond or declined to participate in the study, determining a refusal rate of $2.34 \%$. There was also a loss of 7 workers who answered the questionnaire incompletely, resulting in 10 total losses. The remaining 118 workers correspond to $72.84 \%$ of 162 workers who met the inclusion criteria.

In order to assess the COPSOQ Questionnaire reliability, related to the psychological factors (health), measures were made in variables: General health - evaluation of health conditions as a whole; Vitality - available energy levels and fatigue; Psychological welfare - psychological distress; General stress - conduct of escape from difficulties, 
struggle or contest (behavioral); Physical or psychosomatic symptoms (somatic); Nervousness and irritability (cognitive); Sleep disorders are serious enough to affect normal social, physical, mental and emotional functioning; and Depressive symptoms - in a pathological sense, there is presence of sadness, pessimism, low self-esteem, which often appear and may be combined with each other ${ }^{(28)}$. The responses were grouped according to these steps. Except for sleep disorders (slightly moderate), the mean values for most dimensions of health were statistically significant among municipal transit agents with satisfactory (moderate and good) work ability.

All data collected by means of the WAI and COPSOQ questionnaires completion were recorded and statistically analyzed with the aid of software SPSS $^{\circledR}$ (Statistical Package for Social Sciences) version 20.0.

Descriptive statistical measures were applied, particularly the calculation of measures of central tendency and dispersion (mean and standard deviation).

This study was approved by the Bioethics Committee, under process number 295.418 (Sergio Arouca National School of Public Health).

\section{RESULTS}

The study participants consisted of 118 municipal transit agents, divided in 95 males and 23 females, aged 26-63 years old, 38.29 years on average. As to marital status, most were married $(73.73 \%, n=87)$, followed by single $(17.8 \%, n=21)$ and divorced or separated $(8.47 \%, n=10)$. With regard to the education level, there was a predominance of secondary level $(95.76 \%, n=113)$, followed by high school graduate professionals $(4.24 \%, \mathrm{n}=5)$. The time period working in the function ranged from 1 to 23 years, 5.13 years on average, with $68.64 \%(n=81)$ concentrated between 2 and 11 years.

The work ability index was 36.8 points $(\mathrm{sd}=11.6825)$, ranging from 7.0 to 49.0 points; the prevalence of good capacity for work was $76.27 \%$, with a median of 40.0 points (Table I). It is noteworthy that $35.59 \%$ of workers presented the WAI value between 44 and 49 .

It was observed that there were no significant statistical association between the average score of work capacity and working area of operation $(\mathrm{p}=0.079)$, position $(\mathrm{p}=0.136)$, work shift $(\mathrm{p}=0.622)$, work content $(\mathrm{p}=0.452)$, and salary range $(\mathrm{p}=0.123)$.

Table I - Distribution of the municipal transit agents according to the Work Ability Index (WAI). Rio de Janeiro, RJ, Brazil, 2014.

\begin{tabular}{lccccc}
\hline Work Ability Index Classification & Scores & $\mathbf{n}$ & $\mathbf{x}$ & Sd & $\mathbf{\%}$ \\
\hline Low & $07-27$ & 18 & 13.61 & 5.4232 & 15.25 \\
Moderate & $28-36$ & 10 & 30.9 & 2.5144 & 8.48 \\
Good & $37-43$ & 48 & 38.85 & 4.8662 & 40.68 \\
Excellent & $44-49$ & 42 & 46.69 & 2.1468 & 35.59 \\
\hline
\end{tabular}

x: Mean; Sd: Standard Deviation.

In Table II it is observed that there were significant statistical associations with marital status $(p=0.003)$, income $(p=0.021)$, education level $(p=0.025)$, years in job $(p=0.026)$, and weaker association between the average score of work capacity and age $(\mathrm{p}=0.081)$, and job satisfaction $(\mathrm{p}=0.092)$. The prevalence of good capacity for work was found among the municipal transit agents aged between 31 and 50 years old. However, concerning the job satisfaction, $23.73 \%(n=28)$ denoted being satisfied, $62.71 \%(\mathrm{n}=74)$ reported intermediate satisfaction, and $13.56 \%(n=16)$ are dissatisfied. With regard to habits and lifestyles, it was found higher prevalence of good work ability in $86.44 \%(n=102)$ who rated their general and oral health as good, and in those without signs and symptoms of depression. Also showed good ability those transit agents who were classified as active or very active as to physical activity, into abstinence or alcohol consumption without risk, who do not smoke, have social support from one or more relatives and friends, and participate in group activities such as meetings, volunteer work and religion activities. On the job characteristics, the good work ability was more prevalent among transit agents who had only one job, worked up to 40 hours per week, did not work at night, had high social support at work, and had their jobs classified as low demand, resulting from the combination of low demand and high control.

It was found that the dimensions of health (physical and mental) were positively and significantly associated with the ability to work, regardless of demographic and occupational characteristics (Table III).

Cronbach's alpha is a measure of internal consistency, and reliabilities of the COPSOQ scales are adequate or 
Table II - Analysis of associations between work ability and demographic and occupational characteristics among municipal transit agents. Rio de Janeiro, RJ, Brazil, 2014.

\begin{tabular}{|c|c|c|c|c|c|c|c|}
\hline \multirow{3}{*}{$\begin{array}{l}\text { Variables } \\
\text { (categories) }\end{array}$} & \multicolumn{4}{|c|}{ Work ability } & \multirow{2}{*}{\multicolumn{2}{|c|}{ Total }} & \multirow{3}{*}{ p-value } \\
\hline & & Satisfactory & \multicolumn{2}{|c|}{ Unsatisfactory } & & & \\
\hline & $\mathbf{n}$ & $\%$ & $\mathbf{n}$ & $\%$ & $\mathbf{n}$ & \multirow{2}{*}{$\%$} & \\
\hline Age (years) & & & & & & & \\
\hline$<30$ & 14 & 66.66 & 7 & 33.34 & 21 & 100 & 0.081 \\
\hline $31-50$ & 71 & 92.21 & 6 & 7.79 & 77 & 100 & \\
\hline$>50$ & 15 & 75 & 5 & 25 & 20 & 100 & \\
\hline \multicolumn{8}{|l|}{ Income* } \\
\hline $2-3$ & 43 & 87.75 & 6 & 12.25 & 49 & 100 & 0.021 \\
\hline $4-6$ & 47 & 83.92 & 9 & 16.08 & 56 & 100 & \\
\hline$>7$ & 13 & 100 & 0 & 0 & 13 & 100 & \\
\hline \multicolumn{8}{|l|}{ Education level } \\
\hline Secondary level & 104 & 92.03 & 9 & 7.97 & 113 & 100 & 0.025 \\
\hline Graduate & 6 & 100 & 0 & 100 & 6 & 100 & \\
\hline \multicolumn{8}{|l|}{ Marital status } \\
\hline Single & 13 & 61.9 & 8 & 38.1 & 21 & 100 & 0.003 \\
\hline Married & 74 & 85.06 & 13 & 14.94 & 87 & 100 & \\
\hline Divorced/separated/widowed & 7 & 70 & 3 & 30 & 10 & 100 & \\
\hline \multicolumn{8}{|l|}{ Years in job } \\
\hline $1-2$ & 14 & 77.77 & 4 & 22.23 & 18 & 100 & 0.026 \\
\hline $3-11$ & 75 & 87.21 & 11 & 12.79 & 86 & 100 & \\
\hline$>12$ & \multirow{2}{*}{\multicolumn{3}{|c|}{ x: Mean; Sd: Standard 28 eviation. 5}} & 35.72 & 14 & 100 & \\
\hline Job satisfaction & & & & & & & \\
\hline Satisfied & 28 & 77.77 & 8 & 22.23 & 36 & 100 & 0.009 \\
\hline Intermediate & 59 & 93.65 & 4 & 6.35 & 63 & 100 & \\
\hline Dissatisfied & 16 & 84.21 & 3 & 15.79 & 19 & 100 & \\
\hline
\end{tabular}

*number of minimum wages in Brazilian Reals (R\$)

Table III - Analysis of associations between work ability and dimensions of health among municipal transit agents. Rio de Janeiro, RJ, Brazil, 2014.

\begin{tabular}{|c|c|c|c|c|c|}
\hline \multirow{3}{*}{ Dimension of health } & \multicolumn{4}{|c|}{ Work ability } & \multirow{3}{*}{ p-value } \\
\hline & \multicolumn{2}{|c|}{ Satisfactory } & \multicolumn{2}{|c|}{ Unsatisfactory } & \\
\hline & $\mathbf{x}$ & Sd & $\mathbf{x}$ & Sd & \\
\hline General health & 65.25 & 1.44 & 36.44 & 2.07 & 0.008 \\
\hline Vitality & 72.81 & 2.11 & 12.71 & 1.79 & 0.002 \\
\hline Psychological welfare & 58.47 & 2.87 & 36.44 & 2.29 & 0.007 \\
\hline Behavioral stress & 72.03 & 1.02 & 27.96 & 2.76 & 0.009 \\
\hline Psychosomatic stress & 68.64 & 2.67 & 47.46 & 2.18 & 0.005 \\
\hline Nervousness and irritability & 72.03 & 1.12 & 18.64 & 0.89 & 0.0001 \\
\hline Sleep disorders & 40.68 & 1.43 & 27.12 & 0.54 & 0.002 \\
\hline Depressive symptoms & 60.17 & 1.05 & 21.19 & 2.28 & 0.004 \\
\hline
\end{tabular}

x: Mean; Sd: Standard Deviation.

good in the range of $0.70-0.89^{(28)}$. The consistency of the questionnaires applied was satisfactory (Cronbach's alpha $\geq 0.72$ ). Mean level of satisfaction amongst workers was comparatively high. The results compared to Cronbach's alpha coefficient for the overall scale of the sample $(n=118)$ revealed a high internal consistency. Almost all dimensions obtained Cronbach's alpha coefficients higher than 0.60 (COPSOQ and WAI).

\section{DISCUSSION}

It was observed that the mean level of satisfaction among workers was relatively high. However, it is well known that only a minority of workers actually state their dissatisfaction, which may lead to an underestimated prevalence of dissatisfaction at work. High levels of satisfaction are observed even in adverse situations, 
including accidents, high rates of absenteeism, and inadequate working conditions ${ }^{(29-31)}$. It is necessary to consider other factors relating to work environment that have been identified in the literature but are not contemplated by the WAI, which only covers the aspects related to the worker. Although the factors found in the WAI are central to determining the abilities, limitations and needs of people, it largely ignores issues related to the characteristics of the workplace or the work environment ${ }^{(32)}$.

Education and income were directly related, and both were positively correlated with work ability. In turn, these aspects positively influence health conditions and maintain the ability to work for longer periods. In the present study, all dimensions corresponding to health status were found to be statistically correlated with the WAI. In general, associations between work ability and dimensions related to mental health were verified. In this study, the inclusion of both dimensions is justified by the type of activity performed by the study population.

Working conditions in industrial countries have experienced numerous, partly fundamental changes over the last decades ${ }^{(33)}$. Alongside with comprehensive changes in production conditions and realities in industry, administration and service, demands on the employees are also changing. Time and local flexibility, high toughness or social competences are becoming more and more key qualifications. Consequently, sick leave days and treatment costs due to psychosocial factors have increased systematically ${ }^{(34)}$.

The impact of psychosocial risks is reflected on the health and welfare of workers, organizations and society ${ }^{(35)}$. This impact can lead to negative individual consequences at the physical, psychological and behavioral level and can also bring organizational consequences ${ }^{(30,36)}$. Individual consequences may affect the person at different levels and include: physical symptoms associated with pain (e.g., cramps, headaches), musculoskeletal injuries or disorders, breathing difficulties, allergies, hypertension and cardiovascular disorders, sexual disorders, gastrointestinal disorders, insomnia, immune disorders, embrittlement and fatigue $^{(37)}$; as well as psychological symptoms related to depression and stress, nervousness and increased irritability, crying spells/nerves, increased sadness and anxiety, memory loss and exhaustion, difficulty concentrating and making decisions, emotional instability, subjugation or dependence on others, emotional oscillation and depersonalization ${ }^{(2,4)}$; and finally, the behavioral symptoms that are manifested as isolation, neglect of personal needs (sleeping, eating, socializing), increased alcohol consumption, self-medication and use of drugs, tobacco and caffeine, interpersonal and family conflicts, aggression, lack of cooperation and indifference, missed work and commitment, errors and failures in performance and, in extreme cases, suicide $^{(5)}$.

In summary, the present study made a diagnosis of the impact of psychosocial factors at work on the health and work capacity of municipal transit agents, which could be an important contribution to an in-depth analysis at the points where critical factors were identified, aiming at optimizing work situations and signalling the lack of measures to promote work capacity.

Mental health is considered to be, in general, less correlated to work capacity than physical health ${ }^{(38)}$, and is considered more relevant in works with predominantly mental requirements ${ }^{(39)}$. In the study population, where the content of the work is characterized by mental requirements, all the dimensions of mental health evaluated had an association with the capacity for work.

When the concept of health is thought of in terms of worker's health, the work takes on a central character, both because it requires the worker skills for the work performance, and because of the impacts that physical conditions, relationships and work organization have on the worker ${ }^{(3,6)}$. Therefore, the worker's health can be understood as a concrete and dynamic condition of the worker's willingness to trace and pursue his goals towards physical, psychic and social well-being, which is influenced by the conditions and organization of work and the context in which it is inserted ${ }^{(40,41)}$.

The main limitations of the study are related to time constraints, so these results could not be deepened with a thorough analysis of the work activity. In addition, for future prospects, it was considered that the monitoring of transit agents with longitudinal studies would be relevant.

The aspects considered in the present study are elements that can contribute to the conception and development of measures aimed at preserving the work ability, prioritizing the monitoring and control of occupational stress, with emphasis on the lifestyle health conditions, consequently improving the promotion and the health protection of this category of workers.

\section{CONCLUSION}

In conclusion, the results revealed that better physical and mental health are associated with greater work ability, representing that, the better the worker's health, the greater his work ability. The psychosocial work environment and especially the decision-making autonomy were thus important determinants of self-rated quality of life in this group of transit agents. 


\section{REFERENCES}

1. Tuomi K, Ilmarinen J, Jahkola A, Katajarinne L, Tulkki A. Índice de capacidade para o trabalho. São Carlos: Edufscar; 2005.

2. Riedel N, Müller A, Ebener M. Applying strategies of selection, optimization, and compensation to maintain work ability: a cohort study on work, age, and health in Germany. J Occup Environ Med. 2015;57(5):552-61.

3. Hotopp U. The ageing workforce: a health issue? Econ Labour Market Rev. 2007;1(2):30-5.

4. Oberlinner C, Yong M, Nasterlack M, Pluto RP, Lang S. Combined effect of back pain and stress on work ability. Occup Med (Lond). 2015;65(2):147-53.

5. Sabin-Farrell R, Turpin G. Vicarious traumatization: implications for the mental health of health workers? Clin Psychol Rev. 2003;23(3):449-80.

6. Wisniewski D, Gróss G, Bittencourt R. A influência da sobrecarga de trabalho do enfermeiro na qualidade da assistência pré-natal. Rev Bras Promoç Saúde. 2014;27(2):177-82.

7. Ilmarinen J. Work ability: a comprehensive concept for occupational health research and prevention. Scand J Work Environ Health. 2009;35(1):1-5.

8. Dejours C. Subjetividade, trabalho e ação. Rev Prod. 2004;14(3):27-34.

9, Araújo TM, Graça C, Araújo E. Estresse ocupacional e saúde: contribuições do Modelo Demanda-Controle. Ciênc Saúde Coletiva. 2003;8(4):991-1003.

10. Murta S, Tróccoli B. Avaliação de Intervenção em Estresse Ocupacional. Psicologia: Teoria \& Pesquisa. 2004;20(1):39-47.

11. Jacques MG, Codo W. Saúde mental \& trabalho: leituras. Petrópolis: Vozes; 2002.

12. Cherian J, Singh Z, Bazroy J, Purty AJ, Natesan M, Chavada VK. Study of morbidity pattern among salt workers in Marakkanam, Tamil Nadu, India. J Clin Diagn Res. 2015;9(4):LC01-3.

13. Martinez MC, Latorre MRDO, Fischer FM. Capacidade para o trabalho: revisão de literatura. Ciênc Saúde Coletiva. 2010;15(Suppl 1):1553-61.

14. Emberland JS, Knardahl S. Contribution of psychological, social, and mechanical work exposures to low work ability: a prospective study. J Occup Environ Med. 2015;57(3):300-14.
15. Tabanelli MC, Depolo M, Cooke RMT, Sarchielli G, Bonfiglioli R, Mattioli S, et al. Available instruments for measurement of psychosocial factors in the work environment. Journal International Arch Occupat Environ Health. 2008; 82(1):1-12.

16. Quinlan M, Mayhew C, Bohle P. The global expansion of precarious employment, work disorganization, and consequences for occupational health: a review of recent research. Int J Health Serv. 2001; 31(2):335414.

17. Fischer FM, Oliveira DC, Nagai R, Teixeira LR, Márcio L Júnior, Latorrec MRDO, et al. Job control, job demands, social support at work and health among adolescent workers. Rev Saúde Pública. 2005;39(2):245-53.

18. Dollard MF, Skinner N, Tuckey MR, Bailey $T$. National surveillance of psychosocial risk factors in the workplace: An international overview. Work Stress. 2007;21(1):1-29.

19. McDonough P, Amick BC. The social context of health selection: A longitudinal study of health and employment. Social Sci \& Med. 2001; 53:135-145.

20. Mann S, Holdsworth L. The psychological impact of teleworking: Stress, emotions and health. New Technol Work Employment. 2003;18(3):196-211.

21. Lucchini RG, London L. Global occupational health: current challenges and the need for urgent action. Ann Glob Health. 2014;80(4):251-6.

22. Kristensen TS, Hannerz H, Høgh A, Borg V. The Copenhagen Psychosocial Questionnaire (COPSOQ) - a tool for the assessment and improvement of the psychosocial work environment. Scand J Work Environ Health. 2005;31(6):438-49.

23. Law M, Cooper B, Strong S, Stewart D, Rigby P, Letts L. The Person-Environment-Occupation Model: a transactive approach to occupational performance. Can J Occupat Therapy. 1996;63(1):9-23.

24. García-Rodríguez A, Gutiérrez-Bedmar M, BellónSaameño JA, Muñoz-Bravo C, Fernández-Crehuet Navajas J. Psychosocial stress environment and health workers in public health: Differences between primary and hospital care. Aten Primaria. 2014;47(6):359-66.

25. Rabe M, Giacomuzzi S, Nübling M. Psychosocial workload and stress in the workers' representative. BMC Public Health. 2012;12:909.

26. Ilmarinen J, Tuomi K, Seitsamo J. New dimensions of work ability. Int Congress Series. 2005;1280:3-7. 
27. Ilmarinen J, Tuomi K. Promoting excellent work ability and preventing poor work ability: the same determinants? Results from the Swedish HAKuL study. Occup Environ Med. 2006;63(2):113-20.

28. Thorsen VS, Bjorner BJ. Reliability of the Copenhagen Psychosocial Questionnaire. Scand J Publ Health. 2010; 38(Suppl 3):25-32.

29. Tabatabaei S, Hosseinian S, Gharanjiki B. General Health, Stress associated to the work and job satisfaction of Hormozgan cement factory employees in Iran. Procedia Soc Behav Sci. 2011;30:1897-1901.

30. Roxana AC. Social support as a mediator between emotion work and job satisfaction. Procedia Soc Behav Sci. 2013:84:601-6.

31. Moniarou-Papaconstantinou V, Triantafyllou K. Job satisfaction and work values: Investigating sources of job satisfaction with respect to information professionals. Libr Inf Sci Res. 2015;37(2):164-70.

32. Peralta N, Godoi AGV, Griep RH, Miller L. Validez y confiabilidad del Índice de Capacidad para el Trabajo en trabajadores del primer nivel de atención de salud en Argentina. Salud Colect. 2012;8(2):163-73.

33. Messenger JC. Working time and workers' preferences in industrialized countries: finding the balance. Routledge; 2004.

34. Johnson JV. Control, collectivity and the psychosocial work environment. In: Sauter SL, Hurrell JJ Jr, Cooper CL, editors. Job control and worker health. Chichester: Jon Wiley \& Sons; 1989.

35. Camelo S, Angerami E. Riscos psicossociais no trabalho que podem levar ao estresse: Uma análise da literatura. Ciênc Cuid Saúde. 2008;7(2):232-40.
36. Glina D, Rocha L, Batista M, Mendonça M. Saúde mental e trabalho: uma reflexão sobre o nexo com o trabalho e o diagnóstico com base na prática. Cad Saúde Pública. 2001;17(3):607-16.

37. Strazdins L, D'Souza RM, Lim LL, Broom DH, Rodgers B. Job strain, job insecurity, and health: rethinking the relationship. J Occupat Health Psychol. 2004;9(4):296-305.

38. Nygård $\mathrm{CH}$, Eskelinen L, Suvanto S, Tuomi K, Ilmarinen J. Associations between functional capacity and work ability among elderly municipal employees. Scand J Work Environ Health. 1991;17(Suppl 1):1227.

39. Ilmarinen J, Tuomi K, Klockars M. Changes in the work ability of active employees over an 11-year period. Scand J Work Environ Health. 1997;17(Suppl $1): 49-57$.

40. Assunção AA, Sampaio RF, Nascimento LMB. Agir em empresas de pequena e média dimensão para promover a saúde dos trabalhadores: o caso do setor de alimentos e bebidas. Braz J Phys Ther. 2010;14(1):52-9.

41. Minayo Gomez C, Machado JMH, Pena PGL. Saúde do trabalhador na sociedade brasileira contemporânea. Rio de Janeiro: Editora Fiocruz; 2011.

\section{Mailing address:}

Aldo Pacheco Ferreira

Rua Lepoldo Bulhões, 1480

Bairro: Manguinhos

CEP: 21041-210 - Rio de Janeiro - RJ - Brasil

E-mail: aldopachecoferreira@gmail.com 